\title{
Ecotourism in Amazonas: Future Prospects through Senarios
}

\author{
By Edinelza Macedo Ribeiro* \\ Elimar Nascimento ${ }^{\dagger}$
}

\begin{abstract}
In its concept, Ecotourism generates issues of concern in a world that is growing more aware of its economic, social and environmental crises. As such, it requires alternative strategies to generate economic efficiency, environmental conservation and social inclusion to ensure competitiveness in a context of rapid and profound world changes. The state of Amazonas is known as a National Reference in Ecotourism. Thus, it is the main objective of this study to show scenarios built for the future of ecotourism in the Amazonas Tourism Hub, which is made up of 14 municipalities (15.3\% of the state), 10 of which were chosen for this analysis. This hub has a large concentration of Conservation Units, forming the largest protected area (5.7 million hectares) on the planet (Proecotur, 2009). For our methodology, we used the Godet prospective technique to build these scenarios. This model attempts to produce reflections on the future of its local ecotourism in order to identify public policies consistent with sustainability. The results have pointed to three scenarios: "Rational Optimists (A)", "The Uirapuru Song $(B)$ " and "Ajuricaba $(C)$ ". We have found positive influences in the scenarios in spite of shifts between uncertainties and risks. In a strict sense, there is no ecotourism activity as such in Amazonas since its activities are still in a disordered stage of inception and are driven mainly by market opportunities, which is the prevailing view especially among the administrators involved in its planning. On the good side, these scenarios indicate activity growth in the coming years, although its uncertainties and risks need to be resolved by public policies in the sector.
\end{abstract}

\section{Introduction}

Ecotourism is a typical phenomenon from the end of the 20th century into the 21 st century. It is based on nature and outdoor tourism and seeks to achieve a sustainable development model (Choi, 2006; Wester, 2005). On the international scene, the concept of ecotourism requires economic activities of low environmental impact in areas of significant natural and cultural value.

*Adjunct Professor, University of the State of Amazonas, Brazil.

${ }^{\dagger}$ Associate Professor, University of Brasília, Brazil. 
According to Castrogiovanni, it is agreed among scholars that the practice of ecotourism must only occur when the sustainability paradigm is considered (Castrogiovanni, 2004).

In the global context, authors like Wearing \& Neil (2001), Swarbrooke (2000), Goodwin (1996), Buckley (2003), Boo (2005), Lascuráin - Ceballos (1988) and Lindberg \& Hawkins (2005), among others, present a wealth of knowledge which has guided consistent ways of improving the foundations and the operation of ecotourism.

The Ecotourism Hubs Program in Brazil was created by EMBRATUR and the Institute of Ecotourism of Brazil (IEB) to define a management policy for the consolidation of these hubs following sustainability criteria. The concept of hub, in this analysis, refers to specific priority areas to be operated by government actions to implement projects and norms to attract private investment and boost ecotourism activities in the region. According to Wallingre; Villar (2009 apud Valls, 2002) this is defined as a management policy based on sustainability criteria.

The Amazonas Hub was chosen for this study for a number of reasons, namely the existence of important actors who ensure connectivity in ecotourism activities; environmental fragilities which provide a rich source for environmental analysis; the large concentration of Conservation Units; and a growing interest in the implementation of public policies, especially the Green Corridor project.

This research was developed using a qualitative approach. A substantial part of the methodology was the Godet prospective technique for scenario building. This model is regarded, in the medium and long term, as a means to diagnose the current state of ecotourism in Amazonas and provide information on the future of its local ecotourism in order to identify consistent sustainable public policies.

Finally, this work does not attempt to eliminate the uncertainties for the future or to predict what will happen with ecotourism in the state. Rather, the challenge here is to determine what is ideal for the state to achieve in the near future.

\section{Method}

This research was developed using a qualitative approach. This approach is important for this study because it contains a set of essential features, such as:

The natural environment as a direct source for data collection, its descriptive nature and the meaning that people give to things and life which are important to the researcher and the inductive approach. (Godoy, 1995, p.1).

In the analytical and methodological scenario process, is important for the method to allow for both inductive and deductive approaches (Buarque, 2003). This also receives input from a set of essential combinations in the performance of scenarios. In this process, the scenarios perform according to 
combinations of assumptions about the behavior of the main events and generate a coherent set of singular events. It is important to recognize the advantages of this type of approach to research in order to "understand the phenomena from the viewpoint of the participants in the study and, thus, guide an interpretation of such phenomena". (Carvalho, 2007, p. 13).

For this research, we adopted a survey of secondary data through bibliographical and documental research; unstructured interviews during two exploratory field visits to the selected destinations, which took place in December 2010 and between January and May of 2011; structured interviews with social actors from the federal, state and local government, and from the civil society and the market; and direct and participant observation during the ecotourism and scenarios workshop.

The documents collected are those produced mainly during the time of the preparation of projects, programs and methodologies in Proecotur workshops, from the 1990s until the end of 2012. The field study helped to identify the social actors who represent the tourism sector. The ecotourism Workshop in Amazonas covered interdisciplinary topics related to developmental strategies for tourism in the state of Amazonas. The interviews included leading social actors connected to the subject, such as representatives from the Ministry of Tourism/ Proecotur program. The structured interviews were used in order to ascertain the social actors' understanding of ecotourism in the world, in Brazil and in Amazonas over the past 10 years.

Apart from interviews, reports resulting from the workshop stages were collected, which provided the basis to build the framework of internal conditions which determine the future and for the analysis of the dimensions of sustainability in the scenarios. In order to interpret the actors' perception in the interviews, this study relied on the content analysis technique (Bardin, 1979).

In order to analyze the data obtained in the stages of the research on ecotourism in the state of Amazonas, we used the method of construction of prospective scenarios following the tenets set by Godet (2000) which are adopted in Brazil by Porto, Nascimento e Buarque (2001 ). Overall, this study is supported by exploratory research.

As a result, from this set of combinations based mainly on testimonies given by social actors, the methodological process of scenarios provides an opportunity for dialogues and opinions in a world of great political, social, economic and technological uncertainty, (Schwartz, 2004).

\section{Results}

The development of tourism in the state is based on the guidelines set by the Regional Tourism Plan PNT/MTur (2004). Tourism and ecotourism policies receive incentives from the following programs: Program for the Development of Ecotourism in the Amazon (Proecotur), Tourism Regionalization Program - Routes of Brazil (PRT), National Program of Rural 
Tourism and Family Agriculture (PNTRAF), Sport Fishing in Amazonas, Archaeological Tourism and Tourism in Indigenous Lands and Communities.

According to Magalhães (2001), ecotourism hubs are areas where ecotourism activities are being developed successfully and are being promoted by a varying number of actors; or they are sites with special natural conditions, but rather few activities due to the lack of infrastructure and organization.

As a way to promote the development of tourism activities in Amazonas, the state government, through AMAZONASTUR, has defined two ecotourism hubs: The Amazonas Hub and the Sateré Hub. To date, only the object of this study, the Amazonas Hub (Figure 1), has strategic studies on ecotourism done by the state of Amazonas.

Figure 1. Map of the Geographical Area covered in the Scenarios - Amazonas Ecotourism Hub/Research Coverage Area Amazonas Ecotourism Hubs

MAP OF POLITICAL DIVISION: METROPOLITAN AREA OF MANAUS - AM FIRST TOURIST ROUTE OF THE STATE OF AMAZONAS

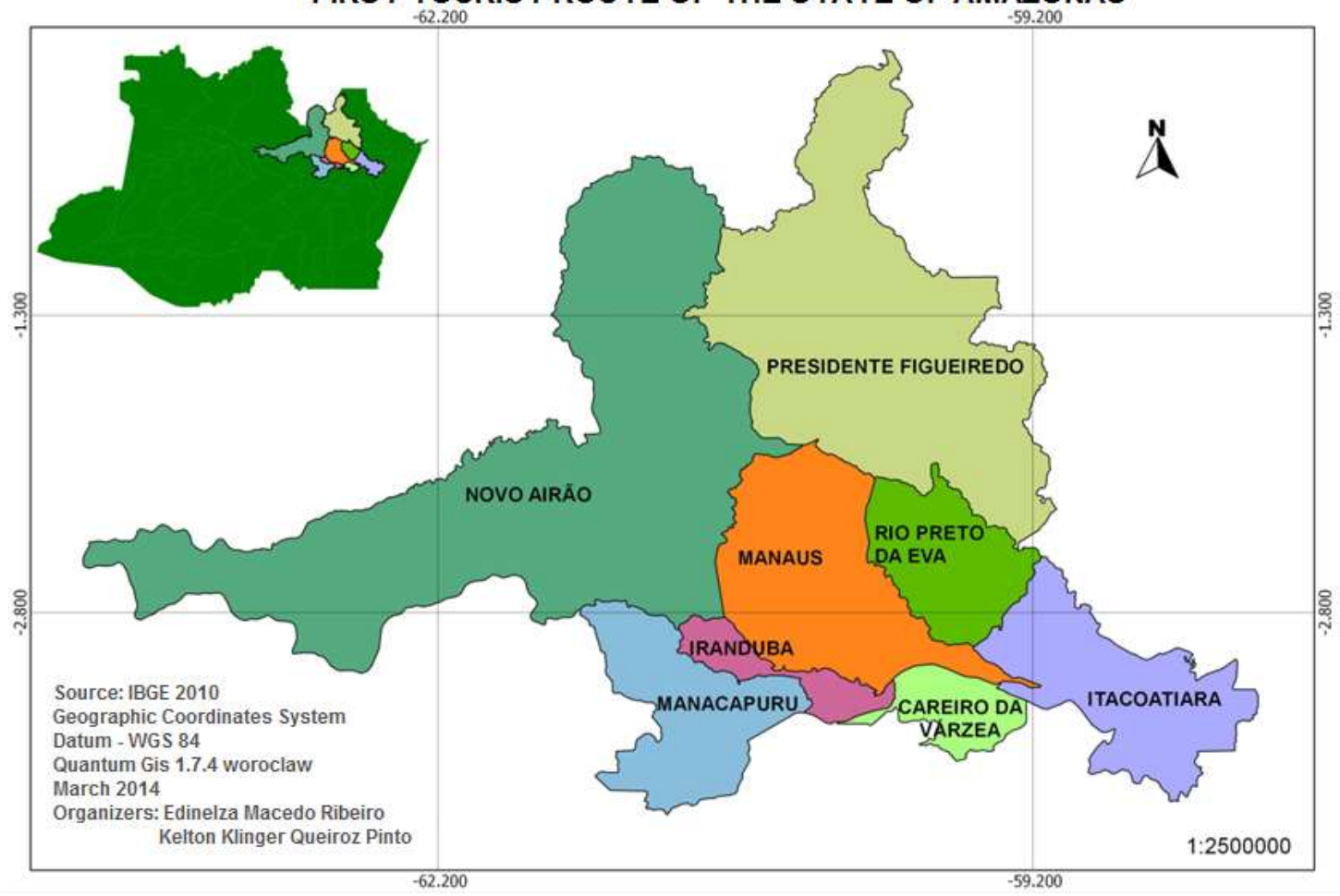

With the exception of Manaus, the municipalities in this study are, on average, $34.6 \%$ without sewage, $39.9 \%$ without garbage collection and $48.1 \%$ without water supply or access to a well. In Careiro, near the capital, $56.1 \%$ of homes are without basic sanitation. The illiteracy rates in the rural areas of these municipalities have not decreased below 15\%, including in Manaus. In Barcelos, $57.6 \%$ of its population is considered illiterate, i.e., with less than eight years of education (IBGE, 2010). These results show a low HDI in these municipalities, causing a social deficit in these destinations in the Amazonas Ecotourism Hub. 
Nevertheless, the municipalities in this hub have unique natural beauties such as islands, waterfalls (Barcelos has the highest waterfall in Brazil and the largest river archipelago in the world - Marirauá with 1,700 islands), the highest mountains in the country (São Gabriel da Cachoeira - Pico da Neblina and 31 de Março). Additionally, these territories also have Conservation Units, lakes, rivers and streams of great beauty.

Amazonas is a unique ecotourism destination when it comes to diversity of indigenous peoples in the region. In São Gabriel da Cachoeira, indigenous people form $97 \%$ of the population (Faria, 2012).

These municipalities are known across the world for their potential as ecotourism destinations (Proecotur, 2009).

The concept of destination can be formed as "a set of tourism products operated within a given geographical area, taking into consideration some common factors among them, such as climate, infrastructure, services and natural and cultural resources". (Wallingre \& Villar, 2009 apud Valls, 2002, p. 22).

The main defining characteristics of ecotourism in the state obtained through the chosen technical approach and the set hypotheses for the critical central uncertainties, between 2012 and 2022, are here presented in three scenarios for Amazonas: Rational Optimists (A), Uirapuru Song (B) and Ajuricaba (C).

\section{Scenario A: Rational Optimists}

Strong climate change - decreasing international, national and regional demand - possible infrastructure improvements - medium quality of services strong competition - public policies of moderate impact - growing local entrepreneurial initiative - growing community participation.

This scenario has a dubious metaphorical meaning. On one hand, it is optimistic about the rich set of variables which create expectations of actions of medium and positive trends. On the other, it is a rational scenario concerned with the risks from the pressures of climate change which may affect the Amazon region from 2012 to 2022. Thus, this scenario describes the development of ecotourism as "on slow gear" unless the state is committed to innovative actions in this sector.

\section{Scenario B: The Uirapuru Song}

Weak climate change - increasing international demand - stability in national and regional demand - constant infrastructure improvement - good quality of services - strong competition - high impact public policies - growing local entrepreneurial initiative - growing community participation.

The Uirapuru is a bird of rare beauty. In the folklore of northern Brazil, it is said to perform one of the most beautiful songs, causing all other birds to stop singing to listen to it. This extensive study process with social actors has produced strong variables which could lead to a breakthrough in the present trends. These breakthroughs can generate favorable cycles that will enhance the growth of ecotourism in the state. Metaphorically speaking, the Uirapuru 
Song is the strengthening of the development of ecotourism in Amazonas, with concrete opportunities of becoming a well-known destination with sustainable standards. The Uirapuru song means the pursuit of ambitious goals and full use of opportunities.

\section{Scenario C: Ajuricaba}

Strong climate change - decreasing international demand - stability in national and regional demand - possible infrastructure improvements - medium quality of services - medium competition - low impact public policies medium but growing local entrepreneurial initiative - growing community participation

Ajuricaba was an indian warrior of the tribe of the Manaós people, hence the name of the capital of the state of Amazonas, Manaus. Ajuricaba was able to gather several tribes to fight against the Portuguese rulers. These extensive studies with the social actors found strong variables which indicate a regression. Here, the fairly positive trends become deeply negative, giving rise to vicious circles which hinder the development of ecotourism activities.

\section{Discussion}

The works by Ribeiro et al (2012) and Ribeiro (2013) on the analysis of ecotourism in Iranduba and a doctoral thesis on ecotourism in Amazonas support local studies and data. Theories by Sachs (2000), Veiga (2002) Leff (2004) and Sen (2010) on the concept of sustainability support the findings in the analysis of the scenarios in economic, social, environmental and infrastructure areas. Rabinovici (2009) supports the analysis of nongovernmental organizations and sustainable tourism.

When looking at the growth prospects of ecotourism-related jobs, scenarios $\mathrm{A}$ and $\mathrm{C}$, at the end of their course, tend to be like Iranduba. In spite of having the largest number of jungle hotels in Amazonas, Iranduba has had in 10 years (2000-2010) a decrease from 532 persons employed in the sector to 403 (IBGE, 2010) and an increase of $38.37 \%$ in deforestation (INPE/Prodes, 2011).

As such, though Iranduba has been considered an ecotourism destination for over 10 years, there are no socioeconomic benefits with regard to the added value of the activities. One example is that the food supplies in the community such as fruits, chicken, fish and others come from Manaus.

The alternatives to this are given over the decade (2012-2022) in scenario A, where they propose a shift in the local tourism, from the activities on offer in the region, to the legalization of businesses and staff training in order to organize the local tourist market.

The promising advantages in scenario B relate to two strategies considered priorities in tourism development in the region. The first relates to technological innovation, especially in clean technology, with new applications in the use of electricity in everyday life in communities in the interior of the 
state of Amazonas. The second is the continued expansion of regional and local supply. One example is the Federal Government program called Luz Para Todos (Light for All). This alternative deals with the construction of hydropower plants, especially in the Amazon, to bring power to rural communities, although at the cost of environmental impacts.

The settings found in scenario B would lean towards sustainability in the social dimension had the projections not shown that fossil fuels will still account for over $80 \%$ of energy supply in 2022. This consumption weakens other investments in clean energy sources with decarbonization trends.

Sociocultural factors in the analysis of scenarios A, B and C are some of the most complex variables in this study since they form the core competence to build the ecotourism sector in the Amazon. This refers to its unique brand which cannot be copied and is a strategy adopted by organizations and companies in order to become recognized in the market.

In this analysis, the core competences of ecotourism in Amazonas in its sociocultural dimension are those found in a range of local ecotourism attractions integrated with its flora and fauna, such as experiencing the traditional communities, conservation units, nature, jungle hotels, boat hotels, food, historical and cultural heritage, cruises and bird watching.

After analyzing the forecasts in scenarios A, B and C, we found that the host communities in this hub can receive positive influence from scenarios shifting from uncertainties to risks. Together, these factors can lead to dead ends, causing a regression in the trends found in scenario $C$ between 2012 and 2022. The consequences of this behavior are grounded on the following weaknesses: ineffective public administration, poor policies to stimulate the sector, difficult coordination between private and government (federal, state and municipal) actors, uneven income distribution in communities and lack of incentives to add value to ecotourism products, as well as the isolation of many rural communities.

In this discussion, it is important to bear in mind the objectives of the National Tourism Plan (2007-2010), which proposes to open the doors to national tourism so that all Brazilians can benefit from this market and its social inclusion (Ministry of Tourism, 2007-2010). Generally, however, the prospect of community participation is controlled by other interests at stake, which aim mainly at strengthening foreign investment in the region.

Thus, despite the unstable development of tourism in scenario $\mathrm{C}$, scenarios $\mathrm{A}$ and $\mathrm{B}$ show a trend of slow change and maturity in organizations that promote ecotourism policies on national and local levels between 2012 and 2022.

Predictions based on the consequences resulting from scenarios A, B and $\mathrm{C}$ in the sociocultural dimension show that over this period of time multiple partnerships will arise based on strategies for self-gain.

In sustainable development, global warming is a variable of great weight. Regardless of the starting point indicated by strong or weak players, from the viewpoint of transformations caused by climate change in scenarios $\mathrm{A}$ and $\mathrm{C}$, the forecast for environmental sustainability is rather discouraging. Meanwhile, 
scenario B shows that the attitudes of decision takers towards deforestation reduction programs from the international community are contradictory.

On one hand, there are positive results with respect to the carbon market. On the other, forecasts show that these deforestation reduction programs bring advantages only to large investors in the region, mainly ranchers, farmers and large landowners. They are promised more compensation for the money they invest in agricultural products once they upkeep or replant their land according to the rules set by REDD.

Forecasts in scenario $\mathrm{C}$ concerning tourism policies in the state indicate future obstacles in various programs to combat deforestation over the time period in this study. The grants from incentive programs of environmental conservation do not reach the traditional communities by the river, extractivists, fishermen nor craftsmen. The goals of these programs are questionable as these factors only tend to hinder the participation of the population in local tourism projects.

Concerning public policies created to stimulate ecotourism in indigenous lands, although scenario $\mathrm{C}$ predicts conflicts between the institutions responsible for these peoples, scenario $\mathrm{B}$ indicates the completion of several projects which will generate economic resources and improve the quality of life of this population.

Finally, demands made by social and environmental programs which only celebrate the reduction of deforestation rates do not solve the problems in Amazonas' society. This is a matter of concern, especially as scenarios A and $\mathrm{C}$ show the poor performance of public policies. Answers to these problems can be found in decisions involving the various sectors because they strengthen the ties between organizations in the locations to be developed. Reforestation, cleaning up the water reserves, basic sanitary infrastructure, proper water consumption management, eradication of traditional diseases, quality of education, economic alternatives designed for the small farmer and other sensitive areas uncovered by public policies bring benefits not only to tourism but to the population at large.

This analysis of scenarios for ecotourism in Amazonas took into account the structural organization of sustainability, namely its superstructure and infrastructure. In this context, superstructure refers to public, private and intrasector organizations whose function is to regulate and create plans and programs for the tourism system. Infrastructure, in turn, refers to providers of basic or support services to the tourism system (telephone network, sewage system, drinking water network, airports, highways, and so on).

An overall assessment of superstructure and the infrastructure aspects in scenarios $\mathrm{A}, \mathrm{B}$ and $\mathrm{C}$ shows unsustainable trends in the forecasts made.

Some factors stemming from uncertainties in climatic changes, such as global warming, fall in agricultural productivity, extraordinary growth of migration flows, among others, tend to influence public policy makers in the region. One aspect that stands out in the forecasts based on scenarios A, B and $\mathrm{C}$ is the indicator of changes in the participation of communities in ecotourism hubs. When strongly integrated, these communities pose a risk to the 
performance of the Ministry of Tourism in promoting social inclusion within the three-level government model. As for the state government, they yet again promise in their speeches to make tourism a priority in their government plans.

Therefore, meeting the goals set in the economic, sociocultural, environmental and structural organization dimensions depends on the creation of knowledge and learning as a heritage of the greatest value. For this, decisions cannot be based on the interests of closed groups, but on the creation of knowledge as a collective and dynamic process which underlines the roles of businesses, public and private companies, and educational institutions, especially universities, as research centers.

\section{Conclusion}

Building future scenarios is a challenge in that it relies on the perception of social actors, but it does bring two advantages, namely the flexibility and the interaction that take place in its stages. This process has made it possible to understand the global reality of decisions and public policies in local ecotourism.

Having said this, a comprehensive look at ecotourism activities in the state enables one to see that they are still in a disordered stage of inception and are driven almost exclusively by market opportunities, which is the prevailing view especially among the administrators involved in ecotourism planning.

This incipient stage becomes evident when comparing socioeconomic indicators in the state and its capital, Manaus, to those in the selected destinations. The largest economic concentration is in the city of Manaus. Thus, public policies geared to ecotourism become vulnerable, especially when there is a change of government, as their actions fail to fulfill major ecological and social roles and go in the opposite direction of projects and actions designed for other destinations in Amazonas.

This result, in effect, produces socioeconomic and environmental benefits below what is expected, compromising, more often than not, the concept of image of the Brazilian ecotourism product in domestic and foreign markets. Thus, the inferences made from the prospects of ecotourism over a 10-year period contradict the precepts held in the assumptions. This result, therefore, characterizes the activity in the state as unsustainable.

It can be seen that scenario $B$ envisions a promising future for the development of ecotourism with sustainable principles. However, the strategies for this segment need to be planned holistically in order to promote an integrated network to support its development. In scenarios A and C, the growth of ecotourism is weakened and seriously affected by the uncertainties and risks of global warming. This trend may serve as a warning about the absence of stimulatory and preventive actions of environmental education and adaptation of the local population. This has been identified as a powerful tool to raise awareness on the risks and consequences of misuse of natural resources. 
Therefore, as evidenced throughout this study, strategies to develop ecotourism in the state have been relegated to the background, thus contributing to the rural exodus. A promising future in ecotourism is a key element for a new development model for the Amazon. This is the challenge.

\section{References}

Bardin, L. (1979). Análise de conteúdo. Lisboa: Edições.

Boo, E. (2005). O planejamento ecoturístico para áreas protegidas. In: Lindberg, K \& Hawkins, E. Ecoturismo: um guia para planejamento e gestão. 5nd ed. São Paulo: SENAC.

BRASIL. (2001). Cenários socioenergéticos da Amazônia, 2000-2020. Brasil: Eletronorte. Available at www.eletronorte.gov.br [February 2001.] (1994). Diretrizes para uma política nacional de ecoturismo. Brasil: MMA/MICT/BAMA/EMBRATUR. Available at www.mma.gov.br [Jan 15th 2009]

(2009) Ministério do Meio Ambiente. Estratégias de ecoturismo/ PROECOTUR. Available at www.mma.gov.br [May 20th 2010]

. (2004). Programa de regionalização do turismo: roteiros do Brasil. Brasil: MTur. Available at www.mma.gov.br. [January 12th 2009]

. (2003). Programa para o desenvolvimento do ecoturismo na Amazônia legal brasileira - PROECOTUR, 2003. Brasil: MTur. Available at <http://www.mma. gov.br/port/ sca/proeco/turverd.html>. [August 26th 2009]

Buarque, S. C. (1999). Metodologias do planejamento do desenvolvimento local e municipal sustentável. 2nd ed. Recife: IICA. Available at <http://www.permear. org.br/pastas/documentos/permacultor4/Planeja_DesLocal.PDF>. [May 10th 2010].

(2003). Metodologia e técnicas de construção de cenários globais e regionais. Brasília: IPEA.

Buckley, R. (2003). 'Natural Area Tourism: Ecology, Impacts and Management'. Annals of Tourism Research, 26(2): 99-497.

Carvalho, R. C. (2007). Turismo nos Lençóis Maranhenses: estudo das representações sociais de atores sobre a situação atual e futura do turismo nos municípios de Barreirinhas e Santo Amaro do Maranhão, MA. Ph.D. diss. Centro de Desenvolvimento Sustentável - CDS. Universidade de Brasília.

Castrogiovanni, A. C. (2004). Turismo, ecoturismo e sustentabilidade: inquietações e possibilidades. In: Gastal, S.\& Moesch, M. M. Um outro turismo é possível (Org.), 1-108. São Paulo: Contexto.

Cavalcante, M. B (2006). 'Ecoturismo no Brasil, visita à natureza'. Revista Mundo Jovem, Porto Alegre, Ano XLIV, n, 369(1), 02-02.

Faria, I. F. (2012). Ecoturismo indígena: território, sustentabilidade, multiculturalismo. São Paulo: Annablume.

Godet, M. (2003). Manual de prospectiva estratégica: da antecipação à ação. Coleção Gestão \& Inovação. Lisboa: Dom Quixote.

. (2000). 'The art of scenarios and strategic planning: tools and pitfalls'. Technological forecasting and social change, 65(1):3-22.

Godoy, A. S. (1995). 'Introdução à pesquisa qualitativa e suas possibilidades'. Revista de Administração de Empresas, 35(2):1-10. 
Goodwin, H. (1996). 'In pursuit of ecotourism'. Biodiversity and conservation. $5(3): 29-277$.

IBGE. (2010). Censo demográfico (2000-2010). Brasil: IBGE. Available at <www. ibge.gov.br> [May 12th 2011].

. (2010). Economia do turismo: uma perspectiva macroeconômica (20032007). Brasil: IBGE. Available at: <http://www.ibge.gov.br> [May 12th 2011].

INPE. (2010). Desmatamento na Amazônia em dois meses (2010). Brasil: INPE. Available at <www.inpe.br>. [April 8th 2010.]

Lascuráin-Ceballos, H. C. (1988). 'The future of ecotourism'. Mexico Journal, V? (17): 17

Leff, E. (2004). Aventuras da epistemologia ambiental: da articulação das ciências ao diálogo de saberes. Translation by Glória Maria Vargas, 1-60. Rio de Janeiro: Garamond.

Lindberg, K. \& Huber, J. R \& Richard, M. (2005). Questões econômicas relativas à gestão do ecoturismo. In: Lindberg, K. \& Hawkins, D. (Org.). Ecoturismo: um guia para planejamento e gestão. 5nd ed. Translation: Leila Cristina de M. Darin. São Paulo: SENAC-SP.

Magalhães, G. W. (Coord.). (2001). Pólos de ecoturismo: Brasil. São Paulo: Terragraph.

OMT. (2010). 'Barômetro mundial do turismo', World Tourism, 8(1): 2-3 Available at <www.world-tourism.org >. [April 25th 2011].

Porto, C. \& Nascimento, E. P. \&; Buarque, S. C. (2001). Cinco cenários para o Brasil: 2001-2003. Rio de Janeiro: Nórdica.

Rabinovici, A. (2009). 'Organizações não governamentais e turismo sustentável: trilhando conceitos de participação e conflitos'. Ph.D. diss. Núcleo de Estudos e Pesquisas Ambientais (NEPAM). Universidade Estadual de Campinas

Ribeiro, E. M et al. (2012). 'Comunidades à margem da sustentabilidade: um olhar sobre o polo ecoturístico de Iranduba (AM)'. Revista Brasileira de Ecoturismo. 5(1):11-16.

Ribeiro, E. M. (2013). 'Prospectiva e sustentabilidade do ecoturismo: o uso da técnica de construção de cenários no estado do Amazonas. Ph.D. diss. Centro de Desenvolvimento Sustentavel (CDS). Universidade de Brasilia.

Sachs, I. (2000). Desenvolvimento includente, sustentável e sustentado. Rio de Janeiro: Garamond.

Sen, A. (2010). Desenvolvimento como liberdade. Translation by Laura Teixeira Motta, 1-459. São Paulo: Companhia das Letras.

Schwartz, P. (2004). A arte da visão de longo prazo. Translation by Luiz Fernando M. Esteves. 1-18. Rio de Janeiro: Best Seller.

Swarbrooke, J. (2000). Turismo sustentável: turismo cultural, ecoturismo e ética. v. 5. São Paulo: Aleph.

Veiga, J. E. (2002). Cidades imaginárias: o Brasil é menos urbano do que se calcula, 57-155. Campinas-SP: Autores Associados.

Wallingre, N. (2009). 'Alternativas de desarrollo de los destinos turísticos'. In: Wallingre, N. \& Villar, A. Desarrollo y gestión de destinos turísticos: políticas y estratégias. Bernal: Universidad Nacional de Quilmes.

Wester, D. (2005). 'Como definir o ecoturismo'. In: Lindberg, K. \& Hawkins. D. E. (Org.). Ecoturismo: um guia para planejamento e gestão. Translation by Leila Cristina de M. Darin, 5nd ed. São Paulo: SENAC. 
